\title{
Forecasting Exogenous Fiscal Variables in the United States
}

Darrel Cohen

Division of Research and Statistics

Federal Reserve Board

dcohen@frb.gov

\author{
Glenn Follette \\ Division of Research and Statistics \\ Federal Reserve Board \\ gfollette@,frb.gov
}

November 5, 2003

Note: The views expressed are those of the authors and do not necessarily represent those of the Board of Governors or the staff of the Federal Reserve System. We would like to thank Frank Russek for providing us with CBO data and Athanosios Orphanides for providing us with his real-time series on the GDP gap. Also we thank Shagufta Ahmed and Sarah Lawson for excellent research assistance. 


\begin{abstract}
This paper provides an introduction to the practice of forecasting "exogenous" components of federal government taxes and spending-policy actions, for short-in the United States. First, we estimate simple models of defense expenditures that are useful for constructing current-quarter forecasts based on incoming daily and monthly spending data. Also, we discuss forecasting policy changes in the context of extending recent empirical work of Alan Auerbach $(2002,2003)$ on fiscal reaction functions. Forecasts of exogenous fiscal actions are an important input into forecasts of the budget deficit, and we compare the forecasts of the budget deficit prepared by the Congressional Budget Office (CBO), the President's Office of Management and Budget (OMB), and the staff of the Federal Reserve Board (FRB). To our knowledge analysis of the FRB forecasts has not been done before.
\end{abstract}




\section{Forecasting Exogenous Fiscal Variables in the United States}

Darrel Cohen and Glenn Follette

\section{Introduction}

This paper provides an introduction to the practice of forecasting "exogenous" components of federal government taxes and spending-policy actions, for short-in the United States. Prospective fiscal actions are an important determinant of forecasts of the budget deficit and the overall economy. Just within the past year, for example, there have been two major "exogenous" events with important fiscal consequences, the war in Iraq and enactment of the Jobs and Growth Tax Relief Reconciliation Act. Although neither event came as a surprise given their widespread coverage by the media, forecasters had to take a position on the magnitude of the incremental defense spending associated with the war as well as the size and composition of the package of tax cuts, prior to their occurrence. Further, judgments about the impetus to aggregate demand from fiscal policy may have implications for the stance of monetary policy.

The remainder of the paper is organized as follows. In section 2, we introduce simple econometric models of defense spending that provide a tool for constructing a forecast for the current quarter based on incoming daily and monthly data; we apply these models to generate a forecast of defense outlays in early 2003 conditional on high-frequency, real-time spending data. In section 3, we discuss forecasting policy changes in the context of extending recent empirical work of Auerbach $(2002,2003)$ on fiscal reaction functions. Forecasts of exogenous fiscal actions are an important input into forecasts of the budget deficit, and, in section 4, we compare the forecasts of the budget deficit prepared by the Congressional Budget Office (CBO), the President's Office of Management and Budget (OMB), and the staff of the Federal Reserve Board (FRB). The most recent publicly available deficit forecasts of OMB and $\mathrm{CBO}$ are for 
fiscal 2003. However, data availability limits analysis of FRB forecasts to sample periods ending in fiscal 1998. To our knowledge analysis of the FRB forecasts has not been done before.

\section{Forecasting “Exogenous" Defense Spending}

\section{A. The Exogeneity of Defense Spending}

Before discussing a model-based approach to forecasting defense spending, it is useful to address the notion that military outlays are "exogenous." We take this to mean that defense spending is determined primarily by factors - such as wars or perceived threats - that are not included in standard macroeconomic models. Indeed, in the literature, it is standard to take defense spending as exogenous. For example, using a narrative approach Ramey and Shapiro (1998) focus on the Korean War (1950:3), the Vietnam War (1965:1), and the Carter-Reagan defense buildup (1980:1) as three exogenous events that led to large military outlays. These exogenous episodes are used as fiscal shocks in the empirical work of Burnside, Eichenbaum, and Fisher (1999). Moreover Robert Hall (1980) has argued that defense spending is one of the few valid instrumental variables available to macroeconomists.

We present new empirical evidence of the exogeneity of defense spending using techniques from the spectral analysis of time series. Recall that the area under the spectrum is the variance of a (stationary) time series, and that the researcher generally is interested in isolating particular frequencies- seasonal, business cycle, or low - that make a relatively large contribution to the variance. In figure 1, we plot the spectrum of the growth rate of real defense 
consumption and investment expenditures on a NIPA basis from 1947:3 to 2003:Q2. ${ }^{1}$ We focus on the growth rate of spending because it is stationary.

As seen, the variance is dominated by low-frequency fluctuations. Indeed, the spectrum values generally are very large over the frequency range roughly between 0 and .30 , corresponding to a period longer than 20 quarters. $^{2}$ Because the spectral approach is nonparametric, with no explicit economic structure imposed, there is not a unique explanation of the spectral peak. One possibility is that it reflects recurring-if not exactly periodic - wartime (hot and cold) fluctuations in defense spending. Over the sample period, there have been the three Ramey-Shapiro episodes as well as the first Gulf War in the early 1990s and the second Gulf War in 2003, all of which can be reasonably viewed as exogenous fluctuations. ${ }^{3}$

We also utilize Granger noncausality tests to provide further evidence of the "exogeneity" of defense spending. ${ }^{4}$ We regress NIPA real defense spending on 2 lags of itself and 2 lags of a measure of economic activity (real GDP). Regressions are run using both levels and growth rates of the variables, using quarterly data for the period 1948:3 to 2003:Q2. The

${ }^{1}$ Consistent with standard practice, we only plot the spectrum over frequencies from 0 to $\pi$; thus, the area under the plotted spectrum is one-half the variance.

2 The null hypothesis that the series is white noise is strongly rejected by both the FisherKappa and the Bartlett-Kolmogorov-Smirnov tests.

3 There also is a much smaller peak at the business cycle frequencies of 0.7 to 0.8 (corresponding to a period between 7 and 8 quarters), suggestive of a bit of cyclical-sensitivity of defense spending; this finding might be worth pursuing in future research.

${ }^{4}$ As noted in Engle, Hendry, and Richard (1983) there are several concepts of exogeneity. Granger causality is related to their concept of "strong exogeneity." Although the Granger test has been used extensively in the literature, it is controversial. For example, Maddala (1988) shows that Granger noncausality does not necessarily imply that a variable is predetermined or strictly exogenous (the concepts of exogeneity as understood in the traditional simultaneous equations literature). With these caveats in mind, we proceed with the analysis. 
null hypothesis (of Granger non-causality) is that the coefficients on the real GDP terms are zero. The standard F-statistic is 1.95 (with critical value of 3.04 at the 5 percent level) when the regression is run in levels, and thus we cannot reject the null hypothesis that economic activity fails to Granger cause defense spending. Moreover, the null cannot be rejected (F-statistic $=$ $3.03)$ when the regression is run in growth rates. The results are robust to alternative lag structures.

In sum, the combination of results from the earlier literature and the new results presented here, although not definitive, support treating defense spending as an exogenous variable.

\section{B. Model-based Forecasts of Defense Spending: Introduction}

Although defense spending is exogenous, its future path is governed by appropriations bills. ${ }^{5}$ Both OMB and CBO provide estimates of the annual spending that will result from these bills that a forecaster can use to create an overall contour of NIPA real defense spending for the next year. High-frequency forecasts of defense spending-for example, for the next few monthscan be formulated using econometric relationships between quarterly, monthly, and daily defense data. Indeed, an important element of many near-term GDP forecasts is the use of highfrequency defense data, parts of which are key source data used by the Bureau of Economic Analysis to construct estimates of current-quarter GDP.

The range of variation in defense spending suggests the difficulty of forecasting. For

${ }^{5}$ In essence, appropriations acts grant budget authority, which is the authority provided by law to enter into obligations that will result in current or future outlays of funds of the federal government. Both $\mathrm{OMB}$ and $\mathrm{CBO}$ have estimated spendout rates that show the historical relationship between new budget authority and government spending. 
example, GDP growth in 2003 has been buffeted by wide variation in real defense spending, ranging from slightly negative growth in the first quarter to an annual growth rate of 45 percent in the second quarter. Fortunately, the severity of the forecasting task is lessened by the availability of data on defense spending on a daily basis from the Daily Treasury Statement (DTS) and on a monthly basis from the Monthly Treasury Statement (MTS).

The DTS, reports nominal defense vendor payments made the previous business day; this comprises about two-thirds of total defense outlays. Most of the excluded outlays are for personnel (civilian and military) expenditures. The MTS is released about two weeks after the end of a month (i.e. after release of the final DTS for the month) and includes personnel costs and some other payments. The MTS and DTS data are not seasonally adjusted. The MTS for the final month of a quarter is released in time to be incorporated into the publication of the first estimate of NIPA seasonally-adjusted quarterly GDP. The NIPA estimates of defense spending differ conceptually from the DTS and MTS figures; for example, the NIPAs include an estimate of consumption of fixed defense capital as well as a timing adjustment for the difference between progress payments and final delivery of defense capital goods. ${ }^{6}$

As we will see, the DTS defense figures are an excellent predictor of the corresponding MTS outlays, and the MTS outlays are a good predictor of NIPA nominal defense expenditures. Indeed, even the DTS for the first month of a quarter provides a useful guide to the first release of NIPA defense spending for the quarter, which is not published for another three months.

${ }^{6}$ The MTS records cash outlays on defense capital goods whether they are for intermediate progress made or for final delivery. The NIPAs record expenditures on capital goods when they are delivered, whereas the work in progress is picked up in private inventory investment. 
C. Model-Based Quarterly Defense Forecasts: The NIPA - MTS Link

We now examine the econometric relationship between defense spending on a NIPA and an MTS basis. Because the MTS data are affected by the number of employee pay dates in a month, whereas the NIPA data on compensation are seasonally adjusted, we initially exclude compensation from both series. In addition, we exclude consumption of fixed capital (CFC) from NIPA defense spending because there is no comparable concept in the MTS cash data. We run regressions using data both in dollars and in percent change form and all variables are expressed at annual rates. The sample period begins in 1984:4, because of a change in MTS methodology that occurred then, and ends in 2002:Q3.

The dependent variable in each equation is NIPA nominal defense spending excluding CFC and compensation in quarter $\mathrm{t}$. In addition to a constant, the regressor is MTS defense spending excluding compensation. The first regression uses the dollar level of MTS spending for the first month of quarter $t$; the second regression uses spending for the first two months of the quarter; and the final regression uses spending for all three months of the quarter. Results are summarized in table II:1. Coefficients on the MTS regressors are highly significant. Further, they rise in value from 0.76 in the first regression to 0.96 in the final regression. The former suggests that about three-quarters of MTS spending for just the first month of a quarter is reflected in the NIPA defense figure for that quarter; the latter suggests that the MTS data, using all the three months of the quarter, are reflected dollar-for-dollar in the NIPA defense figure for the corresponding quarter. Put another way, the difference between the corresponding NIPA and MTS spending figures is essentially a constant (picking up conceptual differences). In addition, the adjusted $\mathrm{R}^{2}$ rises across the three equations suggesting that useful information is gained as 
the quarter proceeds.

Qualitatively similar results hold for alternative formulations. For example, because the underlying data on nominal defense spending are non-stationary (based on standard augmented Dickey-Fuller tests), we have re-run the regressions with data transformed into growth rates. Again the coefficients are highly significant. In addition, their values rise across the three regressions.

Finally, we have considered the relationship between the NIPA and MTS defense data including outlays on personnel; to implement this approach, we have adjusted personnel costs for payment timing shifts across months (using an auxiliary regression). As before, the coefficients are highly significant and the coefficient values (along with the adjusted $\mathrm{R}^{2}$ ) rise across the three regressions reaching a value of 1.0 in the final regression.

D. The MTS - MTS Link

We now show that MTS data for the first month of a quarter is a good predictor of NIPA defense spending in the same quarter, because it also is a good indicator of MTS spending in the second two months of the quarter. We regress the average of MTS defense spending excluding personnel payments for the second two months of a quarter on the corresponding MTS spending figure for the first month (all data recorded at a monthly rate). The coefficient of 0.74 is highly significant and suggests that most of spending in the first month of a quarter gets reflected in spending in the remainder of the quarter. Moreover, spending in the first two months of the quarter provide a strong signal of spending in the final month.

E. The MTS - DTS Link

For high-frequency forecasting purposes, it is possible to predict the monthly level of 
MTS defense spending, excluding compensation from the level of DTS defense vendor payments for that month. Because of data limitations, the sample period is from January 2000 to July 2003. The coefficient on DTS vendor payments is highly significant, with a coefficient a bit larger than one.

\section{F. Summing Up the Econometrics}

The regression results suggest that once we know DTS vendor payments for a given month, we have a pretty good idea about MTS defense spending (excluding personnel); and once we know MTS spending, even in the first month of a quarter, we can make a good prediction of NIPA defense spending for that quarter in part because MTS spending in the first month provides a good signal of MTS spending in the remaining months of the quarter.

G. Case Study - Iraq War of 2003

The previous regression results can be used to generate forecasts of nominal NIPA defense spending for the first half of 2003 (2003:Q3 was not available at the time of writing of the paper). The forecasting task was challenging, given the dramatic swings actually recorded. In nominal terms, defense spending, excluding compensation and $\mathrm{CFC}$, fell at an annual rate of 8 percent ( $\$ 5$ billion) in 2003:Q1, despite being in the middle of a putative war buildup; but then spending in this category rose at an annual rate of 93 percent ( $\$ 43$ billion) in 2003:Q2. ${ }^{7}$

Relative to its fourth-quarter pace, nominal MTS defense spending (excluding personnel) was down in January, and remained low in February and March. Using our NIPA-MTS

7 In nominal terms, total NIPA defense spending rose at an annual rate of about 5 percent in 2003:Q1, only equal to the average annual growth rate since the mid-1990s; by contrast, spending rose at an annual rate of 47 percent in 2003:Q2, the quarter during which combat took place. 
regression results, the change in MTS spending over the first three months of the year (relative to the total over the final three months of 2002) would imply a decline in NIPA spending (excluding compensation and $\mathrm{CFC}$ ) of about $\$ 6$ billion at an annual rate in the first quarter, versus the actual decline of $\$ 5$ billion. In April, MTS spending surged and remained at an elevated level in May and June; this increase would imply a rise in the corresponding NIPA spending category of $\$ 43$ billion at an annual rate in the second quarter, equal to the actual increase.

Moreover, DTS vendor payments provided a good signal of the corresponding MTS spending over the first half of the year. For example, following a subdued pace of spending in the first 3-1/2 months of the year, DTS spending exploded in the second half of April, coincident with enactment of the fiscal 2003 defense supplemental and remained at an elevated level in May and June. Correspondingly, as noted above, MTS spending jumped in April and remained elevated in May and June.

\section{Modeling Policy Actions}

A. Introduction

The literature on policy reaction functions suggests that a modeling approach can be taken to help forecast "exogenous" policy changes, with the possible exception of defense spending as noted in the previous section. Such a model is suggested by the recent work of Alan Auerbach $(2002,2003)$, in which he provides econometric evidence for the post-war period that discretionary policy depends on the lagged values of the GDP gap (defined as potential 
GDP minus actual GDP) and the actual budget surplus. ${ }^{8}$ The results are plausible; they suggest that discretionary policy reacts in a countercyclical manner to the economy (i.e., a cyclical slowdown is followed by expansionary policy) and that policymakers restore fiscal discipline after recent breakdowns (or alternatively that policy is loosened following an improved budget balance).

Based on a loose reading of Auerbach's findings, an analyst may have predicted enactment of a fiscal stimulus package in 2001 and 2002 given the cyclical slowdown and sizable budget surplus entering the period. However, such results give no guidance as to the specifics of a stimulus package, and these specifics are very important in understanding the macroeconomic consequences of the package. For example, a temporary investment incentive likely would have a much different impact on current aggregate demand than a temporary personal income tax cut. Moreover, the relatively small 2003 fiscal package fits with the econometric results since it was enacted when the output gap was positive (but small) and the budget outlook had deteriorated.

Before turning to our new results, we attempt to replicate Auerbach's initial regression (see table III-1) in which the change in the high-employment budget surplus (HEB) is regressed on the lagged GDP gap (GAP) and the lagged budget surplus, both relative to potential GDP, using NIPA quarterly data for the period 1955:2 - 2002:Q4; both the HEB and GDP gap are kindly provided by the CBO (Auerbach's work is based on the same data). We also estimate the model over the period 1993:Q2 - 2002:Q4. We come close to reproducing his results over both

${ }^{8}$ In other specifications, he considers a weighted average of projected future surpluses. In this case, the results suggest that fiscal discipline is restored in the face of impending budget breakdowns. 
sample periods and assume that any differences are attributable to updated data.

As Auerbach notes, one can use these results to determine the dollar size of fiscal package implied by a 1 percentage point increase in the unemployment rate, or equivalently (via Okun's law), a 2 percent drop in output relative to its full-employment level. His estimated coefficient of -0.41 on the gap term over the period since 1993 implies that such a hypothetical change in the gap in quarter $t$ would raise the high-employment deficit nearly $\$ 90$ billion at an annual rate in quarter $\mathrm{t}+1$ (roughly a third of this is offset owing to the policy response to a higher deficit). ${ }^{9}$ He argues that this seems too large and goes on to consider other measures of the change in fiscal stance. We agree that the HEB concept has problems as a measure of "discretionary" fiscal action and welcome the examination of other measures, although we do not pursue such an approach in this paper.

However, we feel that Auerbach is a bit too hasty in giving up on the HEB. It is not obvious that using the results over the post 1993 period to evaluate the policy response to changing economic conditions is appropriate given that there is only one cycle during this period. Using Auerbach's results from the full post-war sample when considering the effect of a 1 percentage point increase in the unemployment rate would yield a policy response of only about $\$ 15$ billion to $\$ 20$ billion. Further, in the remainder of this section, we present additional results suggesting that modeling with the HEB may give sensible ballpark estimates of the fiscal response to changes in budget and economic conditions. In particular, we consider alternative lag structures, the endogeneity of specific spending categories, asymmetries with respect to the

${ }^{9}$ Moreover, the dynamic specification implies that the HEB deficit would continue to widen if the 2 percent drop in output is sustained; indeed, the deficit would reach $\$ 270$ billion, at which point further gap-induced increases would be offset by the reaction to higher deficits. 
state of the cycle, and the use of current rather than real-time NIPA data to evaluate the determinants of discretionary policy.

\section{B. Direct Extensions of Auerbach's Work}

We now turn to several extensions. First, we address the collinearity between the GDP gap and the actual surplus owing to the presence of automatic fiscal stabilizers by replacing the actual surplus with the high-employment surplus. For the full sample, results in table III-1 show that the estimated coefficient on the budget variable is little changed but that the estimated coefficient on the gap is reduced (in absolute value) from -.07 to -.04. For the sample starting in 1993, we find that the estimated coefficient on the gap is reduced from -.41 to -..30.

Second, we note that the results may be influenced by the use of ex-post NIPA data on the GDP gap rather than the "real-time" data available to policymakers at the time of their decisions. For this purpose, we replace the CBO current measure of the GDP gap with a realtime series constructed by Orphanides $(2001,2003) .{ }^{10}$ Figure 2 plots both series; over the full sample period, the contemporaneous correlation coefficient between them is about 0.65 . Over the full sample period, using the real-time gap reduces the estimated coefficient on the gap variable (in absolute value) further down to -.02. Over the sample beginning in 1993, the coefficient on the gap is reduced in half from -.41 (in the Auerbach specification) to -.25 and further down to -.20 when the HEB replaces the NIPA surplus as a regressor. (Adjusting for first-order autocorrelation, reduces the estimated coefficient a bit more.)

Third, we examine whether the responses of policymakers depend on the state of the

${ }^{10}$ We thank our colleague, Athanasios Orphanides, for providing us with his series. He has found that the interpretation of monetary policy history is greatly affected by the use of a real-time series. 
business cycle. Using quarterly data over the full sample period, we regress the change in HEB on the lagged high-employment budget surplus (scaled by potential GDP), on GAP x $\mathrm{D}_{1}$, and on GAP $\times D_{2}$ where $D_{1}$ equals one if the GDP gap is positive and zero otherwise, while $D_{2}$ equals one if the GDP gap is negative and zero otherwise. The results are reported in table III-3. The estimated coefficient on the lagged high-employment surplus is negative and significant. Further, the results are qualitatively the same whether or not the real-time gap is used and whether or not the gap is contemporaneous or lagged. The estimated coefficient on GAP $\times \mathrm{D}_{1}$ is about -.03 and significant (at the 10 percent level) but the coefficient on $\mathrm{GAP} \times \mathrm{D}_{2}$ is not significant, suggesting that policymakers respond when the gap is positive but not when it is negative. Loosely, this says that policymakers have been more active in bad times than in good times over the entire post-war period.

Fourth, we consider alternative measures of the dependent variable. We first replace the change in the HEB surplus with the change in the HEB surplus excluding defense spending to allow for the earlier finding that defense spending is acyclical (i.e., it is not adjusted by policymakers in the face of cyclical swings in activity). Using the entire sample, this leads to broadly similar (and still statistically significant) estimated slope coefficients (table III-1). The similarity of coefficient values implies that variation in the HEB surplus in response to changes in economic activity is in non-defense budget categories, and thus provides further evidence that it is appropriate to treat defense spending as unresponsive to variations in economic activity. We then replace the HEB surplus with the primary HEB surplus (i.e., we exclude interest payments on the debt) which gives estimated slope coefficients roughly equal in value to those obtained when we excluded defense spending. The adjusted $\mathrm{R}^{2}$ for each equation remains fairly low, 
suggesting that taken as a whole the various specifications do not explain much of the variance in fiscal stance even though the individual coefficients are statistically significant.

Fifth, we examine issues related to the simple lag structure in Auerbach's work, namely that the change in fiscal stance in a quarter depends on the GDP gap and the budget surplus in the prior quarter. It is arguable that Congress does not make policy decisions at such a high frequency (indeed most of Auerbach's subsequent regression analysis makes use of semiannual and annual data). However, the issue is complicated because even if Congress makes important policy decisions only once a year, they may be dependent on the most recent quarterly reading of the gap and the budget surplus, and the relationship can vary from Congress to Congress. A definitive answer probably is not possible, but one can examine how robust the results are to some alternative timing assumptions.

To this end, we examine two modifications to the basic setup. First, using quarterly data for the period 1993:Q2 - 2002:Q4, we replace the gap, lagged one period, with the gap alternatively lagged two and four periods; the key results with respect to coefficient size and significance and overall equation fit are little affected. Second, using annual data (table III-2), we regress the change in HEB on the contemporaneous and lagged gap and on the lagged level of the budget surplus. Using the real-time gap, we find that the estimated coefficients on the budget surplus are negative but not significantly different from zero. The estimated coefficient on the contemporaneous gap is about -0.1 and significant, while the sign on the coefficient of the lagged gap switches with specification but is never significant.

In summary, our work suggests that the initial impact of a change in the GDP gap on 
fiscal stance is at most half as large as estimated by Auerbach; also we find that the relationship is stronger when the gap is positive.

C. Extensions Related to Auerbach's Work

We now turn to the response of certain specific programs and spending categories to cyclical and other factors. By convention, the high-employment budget deficit excludes expenditures by the permanent unemployment insurance program (a program comprised of regular benefits for up to 26 weeks). However, the HEB deficit includes expenditures for the temporary extended benefits programs that have been consistently enacted near the end of each recession since the mid-1950s. ${ }^{11}$ In fact, temporary programs existed in $1958-1959$, 1961 - 1962, 1970 - 1973, 1975 - 1977, 1983 - 1985, 1991 - 1994, and 2002 - 2003, suggesting that policymakers responded repeatedly to cyclical fluctuations in labor markets.

To test this hypothesis, we run a regression using monthly data over the period from January 1958 to June 2003. The results are very similar whether we use the linear probability, probit, or logit models (table III-4). For ease of exposition below, we report only the coefficient estimates from the linear probability model. The dummy dependent variable is 1 during the months that the temporary unemployment benefits program was in effect and 0 otherwise, while the independent variable is the unemployment rate. The slope coefficient of 0.16 implies that a 3 percentage point rise in the unemployment rate, typical of most post-war recessions, increases the probability of enactment of a temporary program by about $0.5 .^{12}$

11 The details of temporary extended programs have varied over time; currently the extended program in effect allows benefits up to an additional 13 weeks.

12 We also have estimated the above equation using the unemployment rate for workers unemployed more than 26 weeks; this yields similar qualitative results. 
Of course, enactment of an unemployment insurance program could have a contemporaneous impact on the unemployment rate, i.e., reverse causality is a potential problem. To address this issue, we try the one-month and the four-month lagged values of the unemployment rate alternatively as regressors. The coefficient values and standard errors are barely affected, suggesting that reverse causality is not a major issue. ${ }^{13}$

In the previous section, we argued that defense spending was exogenous. In terms of the annual budgeting process in Congress, which reconsiders the allocation of money to “discretionary" spending every year, any change in defense outlays may have an impact on the budgeted amounts of non-defense discretionary spending. In addition, Congress may respond to business cycles by adjusting non-defense spending; indeed, Auerbach (2003) finds evidence of such a relationship.

We test these hypotheses by regressing the level of non-defense discretionary spending on the contemporaneous and lagged real-time GDP gap and on contemporaneous defense spending, using unified fiscal year data (for the budget variables) for the period from 1950 to 2002; all variables are scaled by potential GDP. By contrast, Auerbach (2003) considers the sensitivity of the change in nondefense outlays to lagged values of the GDP gap and the budget surplus. Results are summarized in table III-5. The estimated coefficient on defense spending is negative and significant; also the coefficient on the contemporaneous gap is negative but insignificant, while the coefficient on the lagged gap is positive and significant. These results support our hypotheses.

13 We also have tried the rate of long-term unemployment as a regressor; the results are little affected. 
However the low Durbin-Watson statistic suggests that autocorrelation is present. After correcting for either first-order or second-order autocorrelation, we find that the estimated coefficient on defense spending is now slightly positive but insignificant; and the estimated coefficient on the contemporaneous gap is negative but insignificant, whereas the estimated coefficient on the lagged gap remains positive and significant. The result for the lagged gap slightly alters and strengthens the Auerbach finding that total discretionary spending is countercyclical (e.g. rising during recessions), albeit not significantly so, over the entire sample period; we find that it is the non-defense component of discretionary spending that is countercyclical and significant.

\section{Forecasting the Budget Deficit: Comparing OMB, CBO, and FRB}

\section{A. Introduction}

Because our focus in this paper is on "exogenous" fiscal actions, it is useful to keep in mind how various government agencies in the United States differ in their treatment of them when constructing forecasts. Economic and budget forecasts of the Administration assume enactment of the President's policy proposals. By contrast, CBO forecasts do not incorporate any policy changes on either the tax or spending sides of the budget; however the CBO is required in its baseline projections to adjust "discretionary spending" (a category that mainly includes purchases of goods and services) for annual increases in projected rates of inflation. In certain circumstances, this convention implicitly introduces prospective policy actions: for example, the CBO's updated baseline projection in August assumed that the supplemental costs associated with the war in Iraq would remain constant in real terms, which would require enactment of a new supplemental. At the FRB, forecasts of the budget and the economy are 
conditioned on what is deemed the most likely set of policy actions. Forecasts of these actions are based on studying the state of the economy, statistical relationships, and actual fiscal developments, including proposals made by the Administration and members of Congress.

Along with economic and technical surprises, unanticipated policy actions lead to errors in forecasts of aggregate economic activity and the budget deficit, even when the projection horizon is only a few months ahead. In this section, we take a first step at comparing OMB, $\mathrm{CBO}$, and FRB forecasts. In particular, we compare forecasts of the budget deficit and its components but do not offer a complete reconciliation in terms of economic, technical, and policy differences.

B. A Test for the "Rationality" of U.S. Budget Forecasts

Table IV-1 presents the unified budget deficit as well as the near-term budget forecasts of the Administration, $\mathrm{CBO}$, and FRB. The FRB forecasts are publicly available only through 1998. ${ }^{14}$ For each agency, we use their forecast for a given fiscal year made at the beginning of the calendar year. ${ }^{15}$

As an illustration, consider the Administration's forecasts of the fiscal 2003 deficit. In January 2002, nine months before the beginning of fiscal 2003, the Administration made its

${ }^{14}$ These forecasts are available through 1996 in downloadable form at the Philadelphia Federal Reserve bank web site: www.phil.frb.org/econ/forecast/greenbookdatasets.html.

${ }^{15}$ Updated forecasts are made periodically throughout the calendar year, but we do not use them because they often do not receive the same careful attention as the beginning-of-year forecast. For example, every July, the Administration publishes an update of the budget outlook in its Mid-Session Review of the Budget; however, these updates often are not based on the type of in-depth analysis that characterizes the beginning-of-year forecasts and, as a result, we have decided not to use them in our statistical tests. The CBO does a more complete re-estimate of its baseline budget projection with its mid-year updates; its monthly budget reviews also occasionally provide updates but often give only a range of values. 
initial projection of the deficit for fiscal 2003 based on its policy proposals which were to be debated and enacted prior to October; the deficit forecast was $\$ 80$ billion. In January 2003 the Administration had revised the forecast to $\$ 304$ billion (and also made its initial forecast of the deficit in fiscal 2004). In fact, the deficit was $\$ 374$ billion, implying a huge forecast error of roughly $\$ 300$ billion when compared to the initial forecast made in January 2002.

We refer to the January 2002 projection for fiscal 2003 as the budget year or 1-year ahead forecast. The January 2003 projection for the fiscal 2003 surplus is referred to as the current-year forecast. On average, the current-year forecasts have been slightly pessimistic by all three

forecasters; by contrast, the one-year ahead forecasts (concerning the budget under consideration by Congress) have tended to be optimistic.

We can test more formally for the "rationality" of the Administration, $\mathrm{CBO}$, and FRB forecasts. To our knowledge, the FRB budget forecasts have not been publicly analyzed before. Maddala (1988, Chapter 10) provides a useful summary of tests for "rationality." We first test the null hypothesis of the unbiasedness of a surplus forecast over the period since the mid1970s. ${ }^{16}$ Letting $\mathrm{SF}(\mathrm{t}-\mathrm{i}, \mathrm{t})$ denote the forecast of the budget surplus in fiscal year $\mathrm{t}$ taken from $\mathrm{OMB}, \mathrm{CBO}$, and FRB budget documents published at the beginning of calendar year $\mathrm{t}-\mathrm{i}$

${ }^{16}$ The definition of a fiscal year of the federal government changed in 1977; since then, the fiscal year has been defined to run from October 1 to the following September 30 (for example, fiscal year 1977 began on October 1, 1977 and ended on September 30, 1978). The regressions are estimated over a sample starting in 1980 because this is the earliest year for which 5-year-ahead data are available. To fix ideas, in the regression for the $\mathrm{i}=0$ case, the first observation is for fiscal 1980; specifically, the value of the forecast for the fiscal 1980 budget surplus is taken from the official budget documents published in January 1980 (the "currentyear" forecast). For the $\mathrm{i}=1$ case, the first observation is for fiscal 1980 published in January 1979 (the "budget-year" or "one-year ahead" forecast), and so on for higher values of $i$. 
$(i=0,1,2,3,4,5)$, and $S(t)$ denote the actual budget surplus in fiscal year $t$, we run the following standard regression for each i:

$\mathrm{S}(\mathrm{t})=\mathrm{a}+\mathrm{b} * \mathrm{SF}(\mathrm{t}-\mathrm{i}, \mathrm{t})+\epsilon(\mathrm{t})$

Under the null hypothesis of rationality, $a=0$ and $b=1$. Results are shown in table IV-2; in the table the surplus measures are scaled by GDP as a simple method of dealing with possible nonstationarity. ${ }^{17}$ As seen, over the full sample starting in 1980, the null is not rejected for the horizons $\mathrm{i}=0,1$ and 2 , as the estimate for a is not statistically different from zero and the estimate of $b$ is not statistically different from 1 . Nevertheless, the two-year ahead forecast $(i=2)$ is not very informative; the point estimates of the coefficients are far from their values under the null, but the standard errors are so large that the null cannot be rejected. In the three-year ahead, fouryear ahead, and five-year ahead cases $(i=3,4,5)$, the null is soundly rejected. Indeed, the sign of the coefficient on the projected surplus tends to be negative at longer horizons and is sometimes significant. These results raise important questions about the usefulness of budget projections beyond the budget year for policymakers and researchers. These forecasts have been found to be useful explaining movements in interest rates and in estimating policy reaction functions; this may reflect the fact that certain economic agents act on the basis of the forecasts.

Another characteristic of rational forecasts is that the variance of the forecast is smaller than the variance of the outcome. Table IV-3 reports results on variances at different horizons over different periods. For short horizons, $\mathrm{i}=0$ and $\mathrm{i}=1$, the variance of the forecasts is roughly equal to the variance of the actual surplus (and when former exceeds the latter, the difference is not significant). Over longer horizons the variance of the OMB forecast tends to decline while

${ }^{17}$ FRB staff forecasts are publicly available only through 1998. 
that of $\mathrm{CBO}$ tends to increase. This probably owes to two factors. For OMB, the decline may reflect the policy goal of moving towards budget balance during most of the last thirty years. By contrast, for $\mathrm{CBO}$, the lack of a policy reaction function may allow it to report surpluses and deficits beyond the range of historical experience. ${ }^{18}$

To get a better sense of why the deficit forecasts are fairly accurate over the first couple of years ahead but then deteriorate rapidly, we examine the underlying receipts and outlays forecasts, using OMB data over the period 1980 - 2003. As seen in table IV-4, the receipts forecast is "rational" only for the current-year forecast; examination of disaggregated receipts data shows that breakdown in the out-year forecasts occurs in both the personal income tax and non-personal income tax receipt categories. By contrast, the outlay forecasts are "rational" in the current and next two years before deteriorating.

C. Other Comparisons of Forecasts

We now examine alternative methods of comparing the forecast performance of OMB, $\mathrm{CBO}$, and FRB with respect to the budget surplus in the current and budget years (recall that FRB forecasts generally do not extend beyond the budget year) over the period 1980 - 1998. In the case of the current-year surplus forecasts, the root mean squared forecast error is smallest for the FRB and next smallest for CBO; for the budget-year forecasts, the root mean forecast errors for FRB and $\mathrm{CBO}$ are very similar and much smaller than that for OMB (table IV-5). When the sample is extended through 2003 (thus dropping the FRB forecasts, which are not publicly available after 1998), the root mean squared forecast errors for CBO are only a bit smaller than

\footnotetext{
${ }^{18}$ Consider the case where the government wanted to move to budget balance by the third year and that this was reflected in its forecasts. Then the variance of the three-year ahead forecast would be zero.
} 
those of OMB for both the current and budget years; over the past five years, CBO's budget-year forecasts evidently have deteriorated substantially whereas those of OMB have improved slightly.

Of course, comparing RMSEs is not a formal statistical test. In this regard, we utilize the uniformly most powerful unbiased test of the equality of expected squared forecast errors described in Granger and Newbold (1986, Chapter 9). The results for the current-year forecast comparison over the period 1980 - 1998 indicate that the null is rejected for a comparison of $\mathrm{CBO}$ and $\mathrm{OMB}$ forecasts $(\mathrm{CBO}$ is better); the null is rejected for a comparison of FRB and OMB forecasts (FRB is better); the null is not rejected for a comparison of FRB and CBO forecasts. The same qualitative results apply for the budget-year forecast comparisons as well.

Finally, we consider the optimal combination of various forecasts of the budget surplus (scaled by GDP). The underlying idea is that one forecast may contain useful information absent in others, and so a weighted average of all the forecasts may be better than any single forecast. To implement this notion, we use the technique discussed in Granger and Newbold (1986, Chapter 9), which is equivalent to regressing the actual value of the surplus on different forecasts. We only consider the optimal combination of two different forecasts at a time. Indeed, the results in table IV-5 indicate that for current-year forecasts over the period 1980 - 1998 the OMB forecast receives a weight of about -1 when combined with the CBO forecast. ${ }^{19}$ When the sample is extended through 2003, the OMB and CBO current-year forecasts now receive roughly equal weights; in the case of the budget-year forecasts, the OMB

19 Using the same procedure with FRB forecasts yields results similar to those of CBO; regressions using FRB and $\mathrm{CBO}$ forecasts yield roughly equal weights. 
forecast again receives a negative weight.

D. Summary of Forecast Comparisons

The forecasting exercises lead to several conclusions. First, the current and budget-year surplus forecasts are "rational," but out-year forecasts are not. Not surprisingly, the surplus forecasts deteriorate with the horizon. Also the receipts forecasts are worse than the outlay forecasts. Second, both a simple comparison of root mean squared forecast errors and a formal test of equality of squared forecast errors reveal that FRB and CBO current-year and budget-year surplus forecasts dominate those of OMB, whereas FRB and CBO forecasts are statistically indistinguishable from each other. Third, the optimal combination of forecasts generally gives negative weight to those of OMB. 


\section{References}

Auerbach, A. J. "Fiscal Policy, Past and Present," Brooking Papers on Economic Activity, No. 1, pp. 75-138, 2003.

Auerbach, A.J. "Is there a Role for Discretionary Fiscal Policy?" In Rethinking Stabilization Policy: Proceedings of a Symposium Sponsored by the Federal Reserve Bank of Kansas City, pp. 109-50, 2002.

Burnside, C., M. Eichenbaum, and J. Fisher. "Assessing the Effects of Fiscal Shocks," Working Paper, Federal Reserve Bank of Chicago, November 1999.

Engle, R., D.F. Hendry, and J.F. Richard. “Exogeneity,” Econometrica, Vol. 51, March 1983, pp. 277-304.

Granger, C. and P. Newbold. Forecasting Economic Time Series, $2^{\text {nd }}$ edition, Academic Press, 1986.

Hall, Robert. "Labor Supply and Aggregate Fluctuations," Carnegie-Rochester Conference Series on Public Policy, vol. 12, pp. 7-33, Spring 1980.

Maddala, G.S. Introduction to Econometrics. Macmillen Publishing Company, New York, 1988

Orphanides, A. "Historical Monetary Analysis and the Taylor Rule," Finance and Economics Discussion Series, 2003-36, Federal Reserve Board, July, 2003.

Orphanides, A. "Monetary Policy Rules Based on Real-Time Data," American Economic Review, vol. 91, September, 2001, pp. 964 - 985.

Ramey, V., and M. Shapiro. "Costly Capital Reallocation and the Effects of Government Spending," Carnegie Rochester conference Series on Public Policy, June 1998, Vol. 48, pp. 145 94. 
Figure 1.

Growth Rate of Real Defense Consumption and Investment 1947:3 to 2003:2

Spectral Density

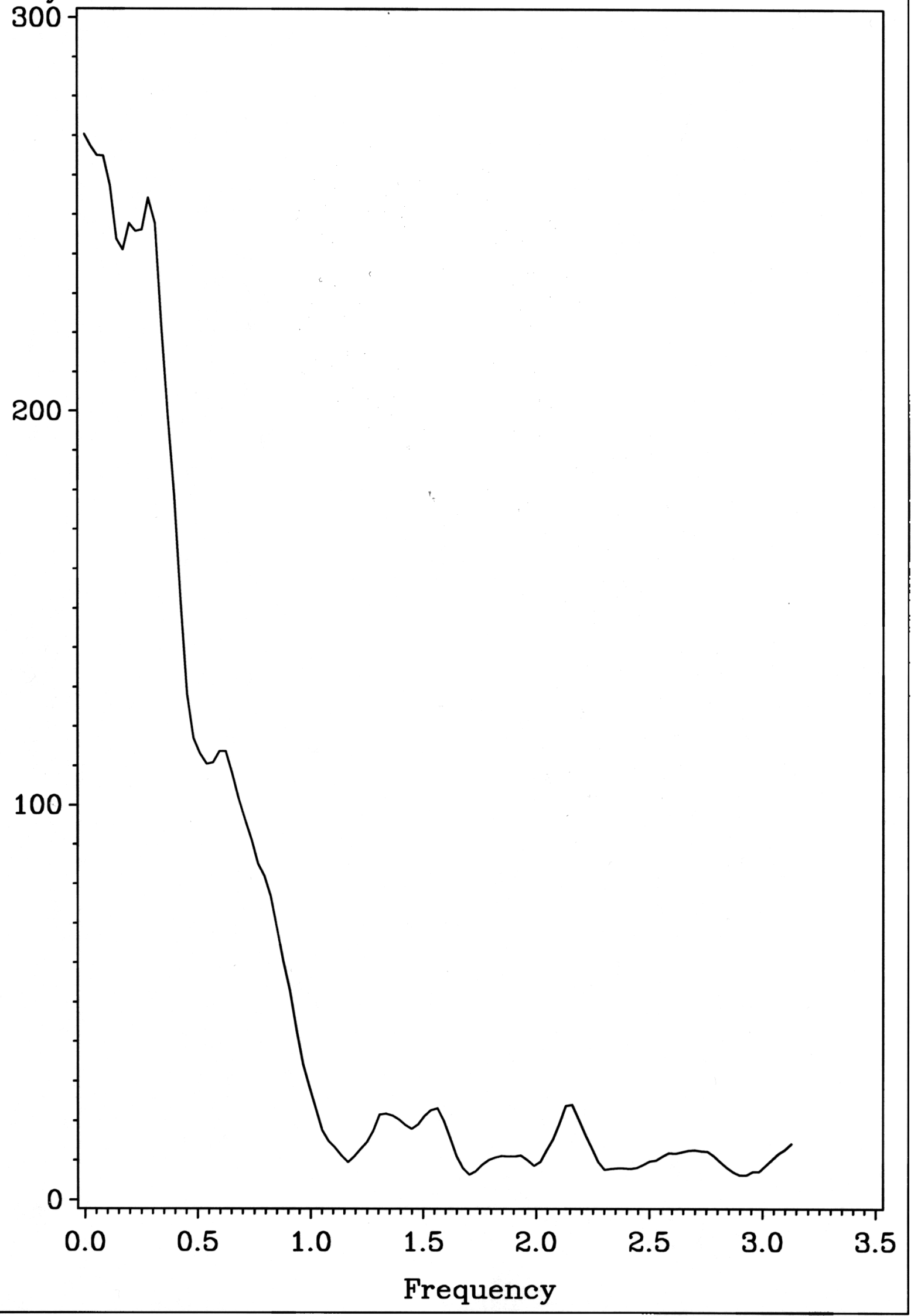


Figure 2

\section{GDP Gap}

Annual

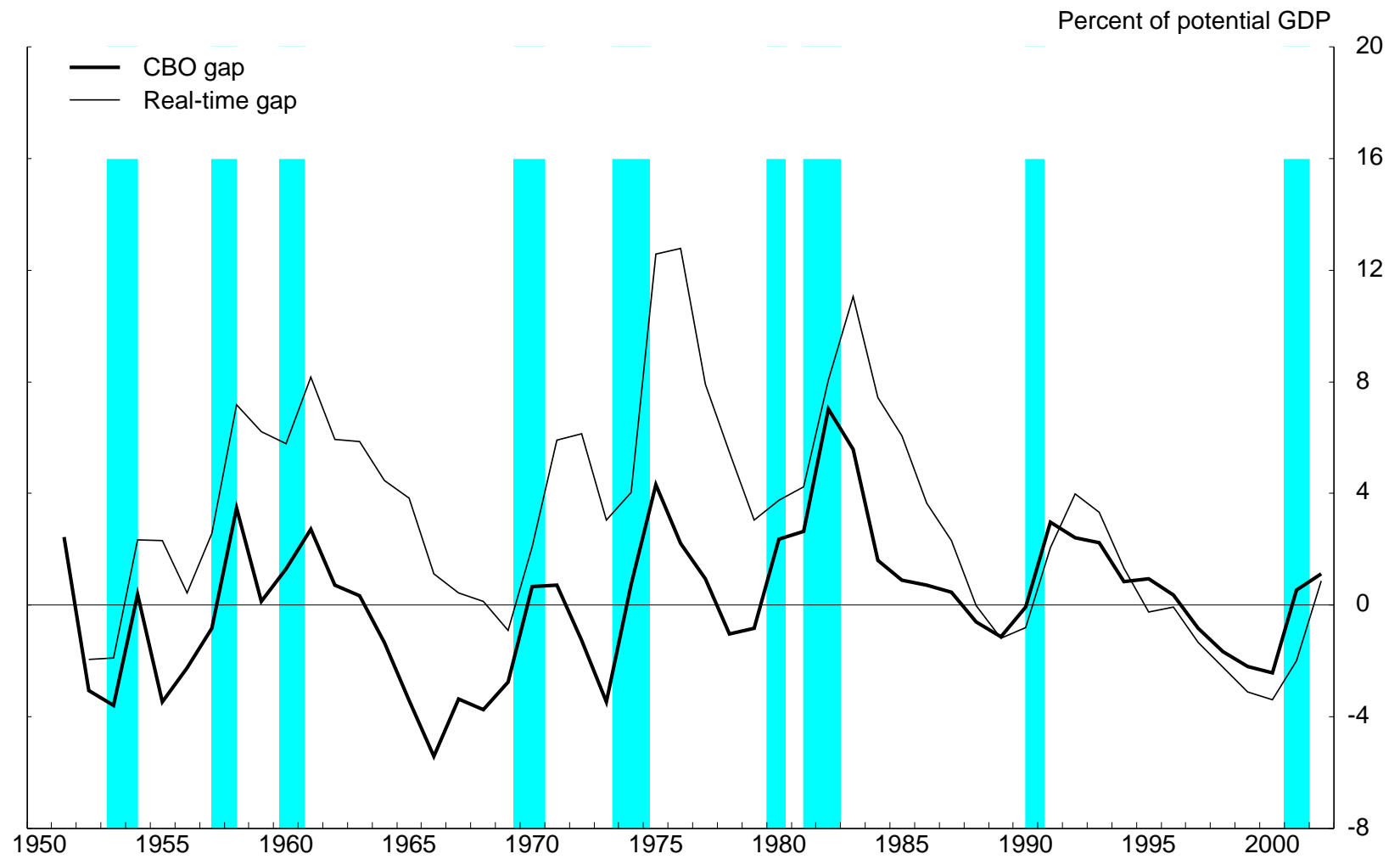

Quarterly

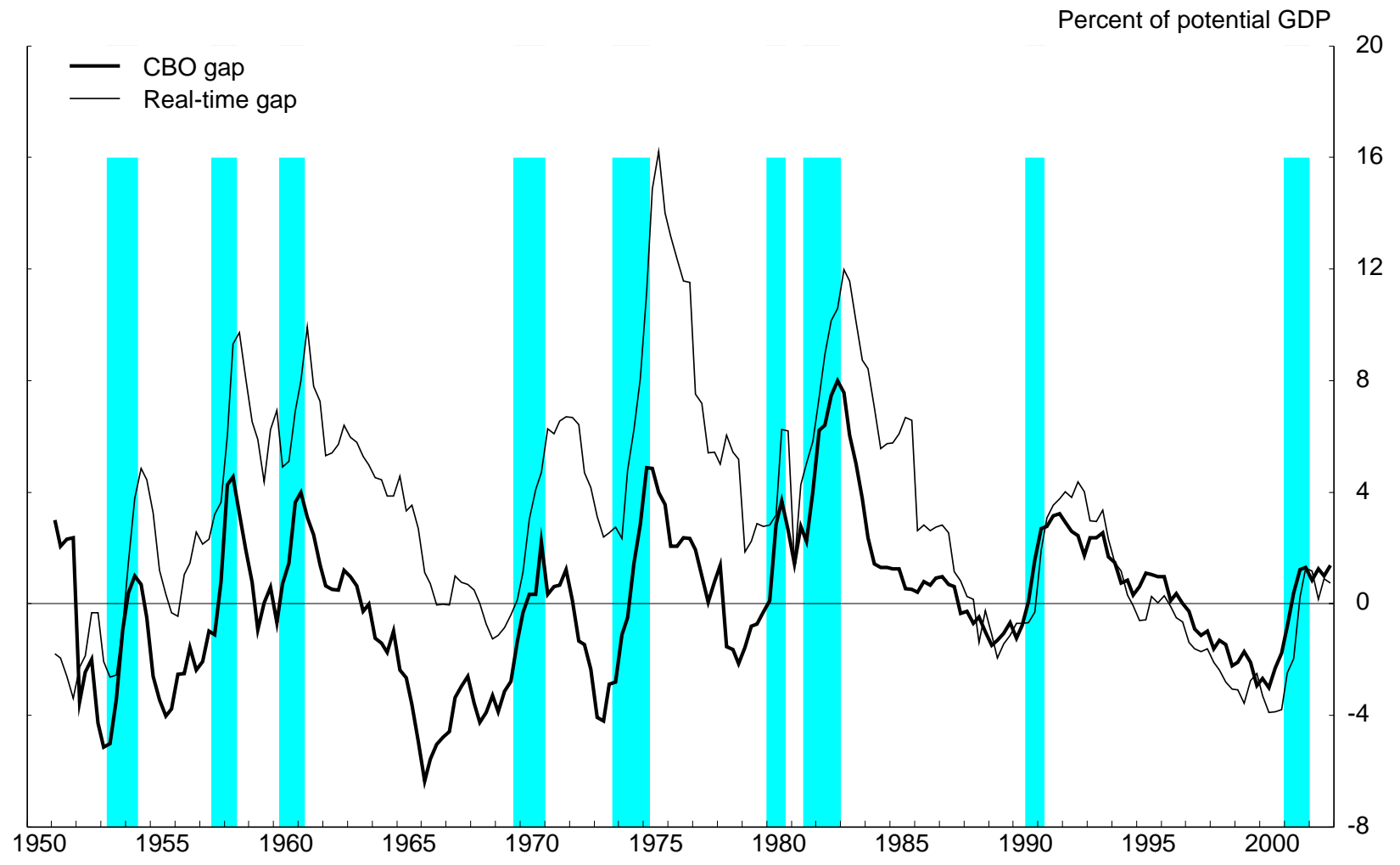




\begin{tabular}{|c|c|c|c|c|c|c|c|}
\hline \begin{tabular}{|l} 
depenendent \\
variable
\end{tabular} & sample period & $\begin{array}{l}\text { levels/pct } \\
\text { chg }\end{array}$ & \begin{tabular}{|l} 
Independent \\
variable
\end{tabular} & coef. & s.e. & Adj. R2 & D.W. \\
\hline NIPA_xcfC_xpers & $1984: 4$ to $2002: 3$ & levels & mts_xpers_1 & 0.76 & 0.06 & 0.663 & 0.90 \\
\hline NIPA_xcfc_xpers & $1984: 4$ to $2002: 3$ & levels & mts_xpers_12 & 0.86 & 0.05 & 0.832 & 1.17 \\
\hline NIPA_xcfc_xpers & $1984: 4$ to $2002: 3$ & levels & mts_xpers_123 & 0.96 & 0.03 & 0.917 & 1.05 \\
\hline NIPA_xcfc_xpers & $1984: 4$ to $2002: 3$ & pct chg & mts_xpers_1 & 0.34 & 0.05 & 0.345 & 2.12 \\
\hline NIPA_xcfc_xpers & $1984: 4$ to $2002: 3$ & pct chg & mts_xpers_12 & 0.52 & 0.06 & 0.488 & 2.15 \\
\hline NIPA_xcfc_xpers & $1984: 4$ to $2002: 3$ & pct chg & mts_xpers_123 & 0.82 & 0.07 & 0.687 & 2.44 \\
\hline NIPA_xcfC & $1984: 4$ to $2002: 3$ & levels & mts_1 & 0.35 & 0.07 & 0.246 & 0.33 \\
\hline NIPA_xcfc & $1984: 4$ to $2002: 3$ & levels & mts_12 & 0.66 & 0.06 & 0.645 & 0.78 \\
\hline NIPA_xcfC & $1984: 4$ to $2002: 3$ & levels & mts_123 & 0.94 & 0.04 & 0.87 & 1.74 \\
\hline NIPA_xcfc & $1984: 4$ to $2002: 3$ & pct chg & mts_1 & 0.08 & 0.02 & 0.168 & 2.06 \\
\hline NIPA_xcfC & $1984: 4$ to $2002: 3$ & pct chg & mts_12 & 0.18 & 0.03 & 0.284 & 2.11 \\
\hline NIPA_xcfC & $1984: 4$ to $2002: 3$ & pct chg & mts_123 & 0.33 & 0.04 & 0.512 & 2.27 \\
\hline NIPA_xcfC & $1984: 4$ to $2002: 3$ & levels & mts_adj_1 & 0.87 & 0.06 & 0.754 & 0.95 \\
\hline NIPA_xcfC & $1984: 4$ to $2002: 3$ & levels & mts_adj_12 & 0.91 & 0.05 & 0.846 & 0.94 \\
\hline NIPA_xcfc & $1984: 4$ to $2002: 3$ & levels & mts_adj_123 & 1.02 & 0.03 & 0.946 & 0.75 \\
\hline NIPA_xcfC & $1984: 4$ to $2002: 3$ & pct chg & mts_adj_1 & 0.27 & 0.04 & 0.402 & 2.01 \\
\hline NIPA_xcfc & $1984: 4$ to $2002: 3$ & pct chg & mts_adj_12 & 0.37 & 0.05 & 0.471 & 2.07 \\
\hline NIPA_xcfC & $1984: 4$ to $2002: 3$ & pct chg & mts_adj_123 & 0.67 & 0.04 & 0.776 & 2.53 \\
\hline mts_xpers_23 & $1984: 4$ & levels & mts_xpers_1 & 0.74 & 0.06 & 0.651 & 1.04 \\
\hline mts_xpers_123 & $1984: 4$ to $2003: 2$ & levels & mts_xpers_12 & 0.81 & 0.10 & 0.462 & 1.37 \\
\hline mts_xpers & \multirow{2}{*}{\multicolumn{2}{|c|}{$\begin{array}{l}2000: 01 \text { to } 2003: 0 ; \text { levels } \\
\text { 2000:01 to } 2003: 0 \text {; pct chg }\end{array}$}} & dts & 1.18 & 0.07 & 0.887 & 2.62 \\
\hline mts_xpers & & & dts & 0.93 & 0.09 & 0.71 & 3.15 \\
\hline mts_xpers & \multirow{2}{*}{\multicolumn{2}{|c|}{$\begin{array}{l}1993: 10 \text { to } 2003: 0 \text { ! levels } \\
1993: 10 \text { to } 2003: 0 \text { ? pct chg }\end{array}$}} & $\mathrm{dts}^{*}$ & 1.33 & 0.09 & 0.797 & 1.73 \\
\hline mts_xpers & & & dts & 0.93 & 0.07 & 0.622 & 2.21 \\
\hline NIPA_xcfc_xpers & \multicolumn{7}{|c|}{$\begin{array}{l}\text { nominal defense consumption and investment expenditures, NIPA basis, excluding CFC } \\
\text { and personnel }\end{array}$} \\
\hline $\begin{array}{l}\text { NIPA_xcfc } \\
\text { mts_xpers_ij }\end{array}$ & \multicolumn{7}{|c|}{$\begin{array}{l}\text { nominal defense consumption and investment expenditures, NIPA basis, excluding CFC. } \\
\text { DoD military outlays, Monthly Treasury Statement, excluding military personnel, for month I } \\
\text { and } \mathrm{J} \text { of the quarter }\end{array}$} \\
\hline mts_adj_ij & \multirow{2}{*}{\multicolumn{7}{|c|}{$\begin{array}{l}\text { DoD military outlays, Monthly Treasury Statement, exclu } \\
\text { and J of the quarter, with personnel costs adjusted for pa } \\
\text { DoD vendor payments (EFT), Daily Treasury Statement }\end{array}$}} \\
\hline dts & & & & & & & \\
\hline $\mathrm{dts}^{*}$ & \multicolumn{7}{|c|}{ r } \\
\hline
\end{tabular}




\begin{tabular}{|c|c|c|c|c|c|}
\hline \multicolumn{6}{|c|}{$\begin{array}{c}\text { Table III-1 Fiscal Policy Reaction to GDP Gaps and Budget Surplus } \\
\text { Quarterly data; 1955:2 to 2002:4 }\end{array}$} \\
\hline \multirow{2}{*}{ dependent variable } & \multicolumn{2}{|c|}{ Surplus measure } & \multicolumn{2}{|c|}{ gap measure } & \multirow{2}{*}{ Adj. R2 } \\
\hline & coef & s.e. & coef & s.e. & \\
\hline & \multicolumn{2}{|c|}{ actual surplus } & \multicolumn{2}{|c|}{ actual gap } & \\
\hline delta_HEB & -0.074 & 0.025 & -0.068 & 0.019 & 0.055 \\
\hline delta_HEB_xdef & -0.070 & 0.024 & -0.062 & 0.019 & 0.052 \\
\hline \multirow[t]{2}{*}{ delta_HEB_xint } & -0.081 & 0.025 & -0.069 & 0.019 & 0.061 \\
\hline & \multicolumn{2}{|c|}{ actual surplus } & \multicolumn{2}{|c|}{ real time gap } & \\
\hline delta HEB & -0.039 & 0.022 & -0.026 & 0.011 & 0.024 \\
\hline delta_HEB_xdef & -0.039 & 0.021 & -0.025 & 0.010 & 0.025 \\
\hline \multirow[t]{2}{*}{ delta_HEB_xint } & -0.044 & 0.022 & -0.024 & 0.011 & 0.023 \\
\hline & \multicolumn{2}{|c|}{ HEB surplus } & \multicolumn{2}{|c|}{ actual gap } & \\
\hline delta_HEB & -0.075 & 0.025 & -0.041 & 0.016 & 0.056 \\
\hline delta_HEB_xdef & -0.071 & 0.024 & -0.036 & 0.015 & 0.052 \\
\hline \multirow[t]{2}{*}{ delta_HEB_xint } & -0.083 & 0.026 & -0.040 & 0.016 & 0.062 \\
\hline & \multicolumn{2}{|c|}{ HEB surplus } & \multicolumn{2}{|c|}{ real time gap } & \\
\hline delta_HEB & -0.066 & 0.025 & -0.020 & 0.010 & 0.042 \\
\hline delta_HEB_xdef & -0.063 & 0.024 & -0.018 & 0.010 & 0.041 \\
\hline delta_HEB_xint & -0.074 & 0.025 & -0.017 & 0.010 & 0.045 \\
\hline \multicolumn{6}{|l|}{ first differences } \\
\hline & \multicolumn{2}{|c|}{ delta surp } & \multicolumn{2}{|c|}{ delta gap } & \\
\hline delta_HEB & -0.236 & 0.071 & -0.126 & 0.048 & 0.055 \\
\hline delta_HEB_xdef & -0.222 & 0.067 & -0.110 & 0.046 & 0.051 \\
\hline \multirow[t]{2}{*}{ delta_HEB_xint } & -0.234 & 0.071 & -0.143 & 0.049 & 0.059 \\
\hline & \multicolumn{2}{|c|}{ delta_surp } & \multicolumn{2}{|c|}{ delta_real time gap } & \\
\hline delta_HEB & -0.260 & 0.068 & -0.136 & 0.036 & 0.090 \\
\hline delta_HEB_xdef & -0.251 & 0.065 & -0.130 & 0.034 & 0.092 \\
\hline \multirow[t]{2}{*}{ delta_HEB_xint } & -0.259 & 0.069 & -0.150 & 0.036 & 0.099 \\
\hline & \multicolumn{2}{|c|}{ delta_HEB surplus } & \multicolumn{2}{|c|}{ delta_gap } & \\
\hline delta_HEB & $-0 . \overline{2} 67$ & 0.071 & -0.040 & 0.044 & 0.069 \\
\hline delta_HEB_xdef & -0.255 & 0.067 & -0.028 & 0.042 & 0.067 \\
\hline \multirow[t]{2}{*}{ delta_HEB_xint } & -0.266 & 0.071 & -0.056 & 0.044 & 0.074 \\
\hline & \multicolumn{2}{|c|}{ delta_HEB surplus } & delta_real & gap & \\
\hline delta_HEB & $-0 . \overline{2} 78$ & 0.069 & -0.086 & 0.033 & 0.098 \\
\hline delta_HEB_xdef & -0.264 & 0.066 & -0.082 & 0.031 & 0.097 \\
\hline delta_HEB_xint & -0.281 & 0.069 & -0.100 & 0.033 & 0.109 \\
\hline Memo: $1993: 2$ to $2002: 4$ & actual s & & actual & & \\
\hline delta_HEB & -0.321 & 0.068 & -0.407 & 0.086 & 0.366 \\
\hline
\end{tabular}

delta_HEB is change in high-employment surplus, _xdef excludes defense expenditures and xint excludes interest expenditures. All variables are scaled by potential GDP. 


\begin{tabular}{|c|c|c|c|c|c|}
\hline \multicolumn{6}{|c|}{$\begin{array}{l}\text { Table III-2 Fiscal Policy Reaction to GDP Gaps and Budget Surplus } \\
\text { Annual data; } 1956 \text { to } 2002\end{array}$} \\
\hline \multirow{2}{*}{ dependent variable } & \multicolumn{2}{|c|}{ Surplus measure } & \multicolumn{2}{|c|}{ gap measure } & \multirow{2}{*}{ Adj. R2 } \\
\hline & coef & s.e. & coef & s.e. & \\
\hline & \multicolumn{2}{|c|}{ actual surplus } & \multicolumn{2}{|c|}{ actual gap } & \\
\hline delta_HEB & -0.16951 & 0.07005 & -0.162 & 0.0552 & 0.135 \\
\hline delta_HEB_xdef & -0.15734 & 0.0676 & -0.14755 & 0.0532 & 0.12 \\
\hline \multirow[t]{2}{*}{ delta_HEB_xint } & -0.1961 & 0.0725 & -0.1572 & 0.0571 & 0.135 \\
\hline & \multicolumn{2}{|c|}{ actual surplus } & \multicolumn{2}{|c|}{ real time gap } & \\
\hline delta_HEB & -0.0885 & 0.0617 & -0.064 & 0.0311 & 0.057 \\
\hline delta_HEB_xdef & -0.0823 & 0.059 & -0.0566 & 0.02992 & 0.044 \\
\hline \multirow[t]{2}{*}{ delta_HEB_xint } & -0.1087 & 0.064 & -0.0502 & 0.03249 & 0.038 \\
\hline & \multicolumn{2}{|c|}{ HEB surplus } & \multicolumn{2}{|c|}{ actual gap } & \\
\hline delta_HEB & -0.16636 & 0.0708 & -0.0992 & 0.044 & 0.129 \\
\hline delta_HEB_xdef & -0.15028 & 0.0684 & -0.0887 & 0.0428 & 0.109 \\
\hline \multirow[t]{2}{*}{ delta_HEB_xint } & -0.193 & 0.0733 & -0.0846 & 0.0458 & 0.128 \\
\hline & \multicolumn{2}{|c|}{ HEB surplus } & \multicolumn{2}{|c|}{ real time gap } & \\
\hline delta_HEB & -0.141 & 0.0709 & -0.0499 & 0.0283 & 0.094 \\
\hline delta_HEB_xdef & -0.127 & 0.0685 & -0.04343 & 0.0247 & 0.075 \\
\hline delta_HEB_xint & -0.193 & 0.0733 & -0.0846 & 0.0458 & 0.128 \\
\hline
\end{tabular}

See notes to table III-1. 


\begin{tabular}{|c|c|c|c|c|}
\hline \multicolumn{5}{|c|}{$\begin{array}{c}\text { Table III-3 Testing for Asymmetric Response } \\
\text { dependent variable: change in high-employment surplus } \\
\text { Quarterly data, } 1955: 2 \text { to } 2002: 4\end{array}$} \\
\hline & $\operatorname{HEB}(\mathrm{t}-1)$ & gap $(\mathrm{t}-1)^{\star} \mathrm{d} 1$ & gap $(\mathrm{t}-1)^{\star} \mathrm{d} 2$ & Adj R2 \\
\hline coef & -0.075 & -0.043 & -0.038 & 0.051 \\
\hline \multirow[t]{2}{*}{ s.e. } & 0.025 & 0.026 & 0.030 & \\
\hline & $\operatorname{HEB}(t-1)$ & $\operatorname{rtgap}(\mathrm{t}-1)^{\star} \mathrm{d} 1$ & $\operatorname{rtgap}(\mathrm{t}-1)^{\star} \mathrm{d} 2$ & \\
\hline coef & -0.066 & -0.019 & -0.025 & 0.037 \\
\hline \multirow[t]{2}{*}{ s.e. } & 0.025 & 0.011 & 0.022 & \\
\hline & $\operatorname{surp}(t-1)$ & $\operatorname{gap}(t-1)^{*} \mathrm{~d} 1$ & $\operatorname{gap}(t-1)^{*} d 2$ & \\
\hline coef & -0.074 & -0.070 & -0.065 & 0.050 \\
\hline \multirow[t]{2}{*}{ s.e. } & 0.025 & 0.029 & 0.032 & \\
\hline & $\operatorname{surp}(t-1)$ & $\operatorname{rtgap}(\mathrm{t}-1)^{\star} \mathrm{d} 1$ & $\operatorname{rtgap}(\mathrm{t}-1)^{\star} \mathrm{d} 2$ & \\
\hline coef & -0.039 & -0.026 & -0.027 & 0.019 \\
\hline \multirow[t]{2}{*}{ s.e. } & 0.022 & 0.012 & 0.022 & \\
\hline & $\operatorname{HEB}(\mathrm{t}-1)$ & $\operatorname{gap}(t)^{\star} d 1$ & $\operatorname{gap}(t)^{*} d 2$ & \\
\hline coef & -0.069 & -0.048 & -0.007 & 0.038 \\
\hline \multirow[t]{2}{*}{ s.e. } & 0.025 & 0.028 & 0.032 & \\
\hline & $\operatorname{HEB}(\mathrm{t}-1)$ & $\operatorname{rtgap}(\mathrm{t} l)^{*} \mathrm{~d} 1$ & $\operatorname{rtgap}(t)^{*} d 2$ & \\
\hline coef & -0.063 & -0.019 & -0.021 & 0.037 \\
\hline s.e. & 0.025 & 0.011 & 0.023 & \\
\hline
\end{tabular}

D1 =1 if gap $>0 ; 0$ otherwise

D2 $=1$ if gap $<0,0$ otherwise. 


\begin{tabular}{|c|c|c|c|}
\hline \multicolumn{4}{|c|}{ Table III-4: Extended Unen } \\
\hline \multicolumn{4}{|c|}{ sample period: $1958: 01$ to $2003: 6$} \\
\hline \multirow[t]{2}{*}{ method } & \multicolumn{3}{|c|}{ independent variables } \\
\hline & measure & coefficient & s.e. \\
\hline linear probability & $\mathrm{ur}(\mathrm{t})$ & 0.16 & 0.01 \\
\hline linear probability & $\operatorname{ur}(\mathrm{t}-1)$ & 0.16 & 0.01 \\
\hline linear probability & $\operatorname{ur}(\mathrm{t}-4)$ & 0.17 & 0.01 \\
\hline linear probability & ur_26(t) & 0.61 & 0.04 \\
\hline linear probability & ur_26(t-1) & 0.61 & 0.04 \\
\hline linear probability & ur_26(t-4) & 0.57 & 0.04 \\
\hline logit & $\operatorname{ur}(\mathrm{t})$ & 0.91 & 0.09 \\
\hline logit & $\operatorname{ur}(\mathrm{t}-1)$ & 0.97 & 0.10 \\
\hline logit & $\operatorname{ur}(\mathrm{t}-4)$ & 1.08 & 0.10 \\
\hline logit & ur_26(t) & 4.08 & 0.37 \\
\hline logit & ur_26(t-1) & 4.05 & 0.37 \\
\hline logit & ur_26(t-4) & 3.55 & 0.34 \\
\hline probit & $\operatorname{ur}(\mathrm{t})$ & 0.54 & 0.05 \\
\hline probit & $\operatorname{ur}(\mathrm{t}-1)$ & 0.57 & 0.05 \\
\hline probit & $\mathrm{ur}(\mathrm{t}-4)$ & 0.64 & 0.06 \\
\hline probit & ur_26(t) & 2.29 & 0.19 \\
\hline probit & ur_26(t-1) & 2.29 & 0.19 \\
\hline probit & ur_26(t-4) & 2.05 & 0.18 \\
\hline \multirow[t]{2}{*}{ probit } & ur_26(t) & 0.03 & 0.08 \\
\hline & ur_26 & 2.22 & 0.29 \\
\hline \multicolumn{4}{|c|}{$\begin{array}{l}\text { Dependent variable equals } 1 \text { when temporary extended } \\
\text { unemployment benefits are available and } 0 \text { otherwise. }\end{array}$} \\
\hline \multicolumn{4}{|c|}{$\begin{array}{l}\text { ur(t): civilian unemployment rate, time } t \\
\text { ur_26(t): civilian unemployment rate of those unemployed } \\
27 \text { weeks or longer, time } t\end{array}$} \\
\hline
\end{tabular}




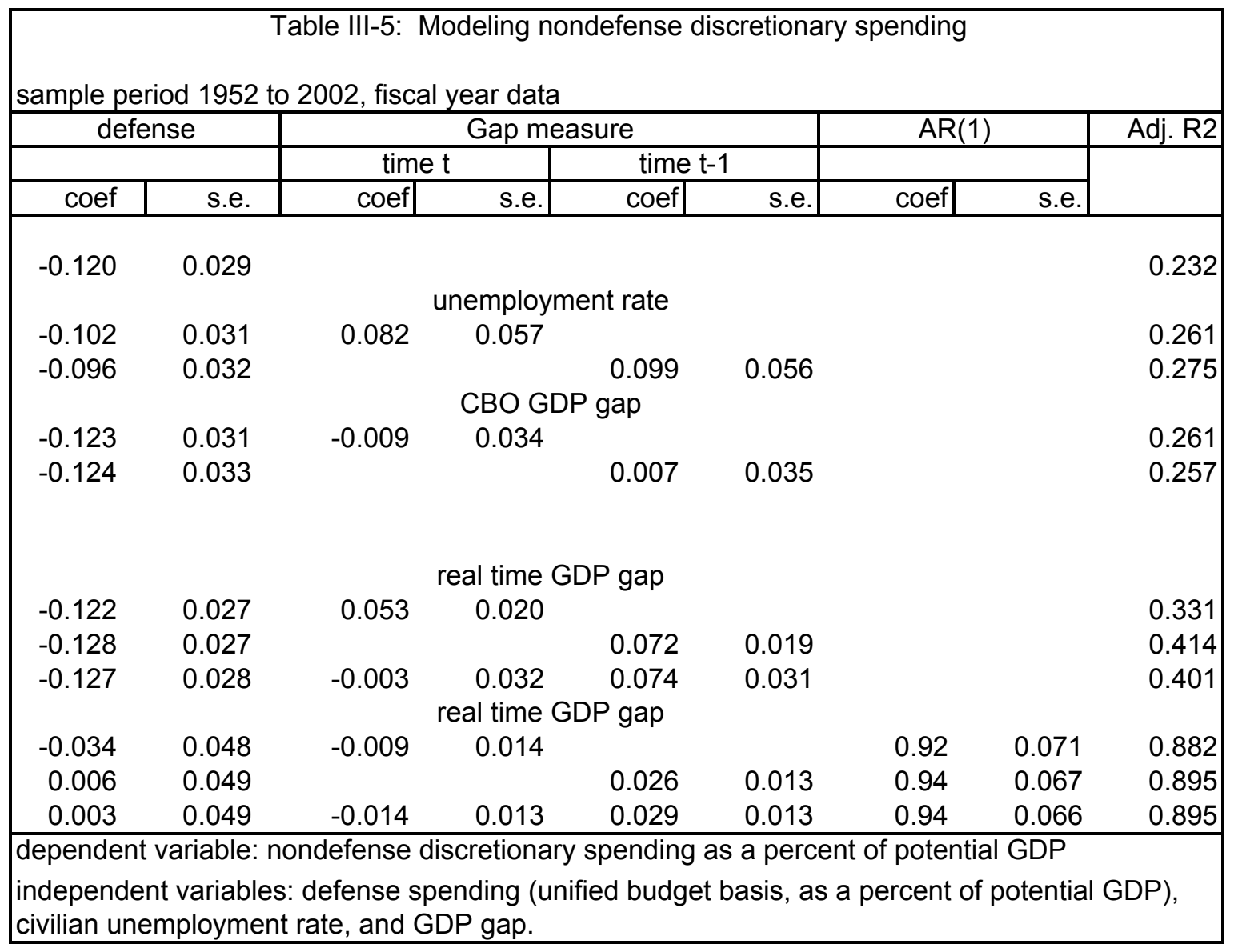




\begin{tabular}{|c|c|c|c|c|c|c|c|}
\hline \multicolumn{8}{|c|}{$\begin{array}{c}\text { Table IV-1 Federal Unified Budget Surplus Projections } \\
\text { Percent of GDP }\end{array}$} \\
\hline & & \multicolumn{3}{|c|}{ Current year forecast } & \multicolumn{3}{|c|}{ Budget year forecast } \\
\hline fiscal year & Surplus & $\mathrm{OMB}$ & CBO & FRB & $\mathrm{OMB}$ & CBO & FRB \\
\hline 1977 & -2.7 & -3.4 & -2.6 & -3.5 & -2.7 & -2.2 & n.a. \\
\hline 1978 & -2.7 & -3.3 & -2.7 & -2.9 & -2.5 & -1.5 & n.a. \\
\hline 1979 & -1.6 & -2.0 & -1.6 & -1.4 & -2.9 & -2.0 & n.a. \\
\hline 1980 & -2.7 & -2.1 & -2.5 & -2.2 & -1.5 & -2.1 & -1.2 \\
\hline 1981 & -2.6 & -2.5 & -2.3 & -2.6 & -1.1 & -1.6 & -1.9 \\
\hline 1982 & -4.0 & -3.7 & -4.0 & -3.9 & -1.4 & -5.4 & -3.1 \\
\hline 1983 & -6.0 & -6.5 & -6.1 & -6.3 & -3.1 & -6.2 & -4.6 \\
\hline 1984 & -4.8 & -5.2 & -5.3 & -5.3 & -5.3 & -5.4 & -5.6 \\
\hline 1985 & -5.1 & -5.4 & -5.2 & -5.3 & -4.7 & -5.3 & -5.1 \\
\hline 1986 & -5.0 & -4.6 & -4.7 & -4.6 & -4.1 & -4.1 & -4.4 \\
\hline 1987 & -3.2 & -3.7 & -3.7 & -3.9 & -3.1 & -3.6 & -3.6 \\
\hline 1988 & -3.1 & -2.9 & -3.1 & -3.2 & -2.2 & -3.5 & -2.9 \\
\hline 1989 & -2.8 & -3.0 & -2.9 & -2.9 & -2.4 & -2.6 & -2.7 \\
\hline 1990 & -3.8 & -2.2 & -2.4 & -2.4 & -1.6 & -2.4 & -2.2 \\
\hline 1991 & -4.5 & -5.4 & -5.0 & -4.8 & -1.1 & -4.8 & -2.0 \\
\hline 1992 & -4.7 & -6.4 & -5.7 & -6.0 & -4.5 & -5.3 & -4.4 \\
\hline 1993 & -3.9 & -5.1 & -4.7 & -4.5 & -5.3 & -4.4 & -5.3 \\
\hline 1994 & -2.9 & -3.4 & -3.2 & -3.1 & -3.8 & -2.5 & -4.4 \\
\hline 1995 & -2.2 & -2.6 & -2.4 & -2.5 & -2.3 & -2.8 & -2.6 \\
\hline 1996 & -1.4 & -1.9 & -1.9 & -2.1 & -2.6 & -2.2 & -2.2 \\
\hline 1997 & -0.3 & -1.5 & -1.5 & -1.3 & -1.7 & -1.5 & -2.4 \\
\hline 1998 & -0.3 & -1.5 & -0.1 & 0.0 & -1.6 & 0.0 & -1.4 \\
\hline 1999 & 0.8 & -0.1 & 1.2 & n.a. & -1.3 & 1.4 & n.a. \\
\hline 2000 & 1.3 & 0.8 & 1.8 & n.a. & 0.1 & 1.8 & n.a. \\
\hline 2001 & 2.4 & 1.7 & 2.8 & n.a. & 1.2 & 3.1 & n.a. \\
\hline 2002 & -1.5 & -1.0 & -0.2 & n.a. & 2.2 & -0.1 & n.a. \\
\hline 2003 & -3.5 & -2.8 & -1.9 & n.a. & -0.7 & -1.4 & n.a. \\
\hline $1980-1998$ & & & & & & & \\
\hline average error & & 0.3 & 0.2 & 0.2 & -0.5 & 0.1 & -0.1 \\
\hline Standard deviation & & 0.8 & 0.6 & 0.6 & 1.5 & 0.8 & 1.2 \\
\hline 1977-2003 & & & & & & & \\
\hline average error & & 0.3 & 0.0 & n.a. & -0.4 & -0.2 & n.a. \\
\hline Standard deviation & & 0.7 & 0.7 & n.a. & 1.7 & 0.9 & n.a. \\
\hline
\end{tabular}




\begin{tabular}{|c|c|c|c|c|c|c|c|}
\hline \multicolumn{8}{|c|}{$\begin{array}{l}\text { Table IV-2: Test for Rationality of Projections: } \\
\text { equation: } \mathrm{S}(\mathrm{t})=\mathrm{a}+\mathrm{b}^{*} \mathrm{SF}(\mathrm{t}-\mathrm{i})+\mathrm{e}\end{array}$} \\
\hline Forecast horizon & Forecaster & period & a & s.e. & b & s.e. & $\begin{array}{l}\text { Adjusted } \\
\text { R2 }\end{array}$ \\
\hline \multicolumn{8}{|l|}{ Budget surplus } \\
\hline current year, i=0 & OMB & $1950-2003$ & -0.05 & 0.14 & 0.88 & 0.05 & 0.864 \\
\hline current year, $\mathrm{i}=0$ & OMB & $1950-1976$ & -0.06 & 0.18 & 0.83 & 0.10 & 0.715 \\
\hline current year, $\mathrm{i}=0$ & OMB & $1977-2003$ & -0.07 & 0.23 & 0.88 & 0.06 & 0.885 \\
\hline current year, $\mathrm{i}=0$ & CBO & $1977-2003$ & -0.24 & 0.21 & 0.90 & 0.06 & 0.886 \\
\hline current year, $\mathrm{i}=0$ & OMB & $1980-1998$ & -0.12 & 0.41 & 0.88 & 0.10 & 0.801 \\
\hline current year, $i=0$ & $\mathrm{CBO}$ & $1980-1998$ & 0.19 & 0.34 & 0.99 & 0.09 & 0.871 \\
\hline current year, $\mathrm{i}=0$ & FRB & $1980-1998$ & 0.13 & 0.35 & 0.97 & 0.09 & 0.863 \\
\hline budget year, i=1 & OMB & $1950-2003$ & -0.82 & 0.27 & 0.67 & 0.11 & 0.384 \\
\hline budget year, i=1 & OMB & $1950-1976$ & -0.87 & 0.27 & 0.26 & 0.17 & 0.048 \\
\hline budget year, i=1 & OMB & $1955-1976$ & -0.85 & 0.28 & 0.54 & 0.25 & 0.144 \\
\hline budget year, i=1 & OMB & $1977-2003$ & -0.86 & 0.48 & 0.78 & 0.16 & 0.477 \\
\hline budget year, i=1 & CBO & $1977-2003$ & -0.86 & 0.42 & 0.73 & 0.13 & 0.533 \\
\hline budget year, i=1 & OMB & 1980-1998 & -1.49 & 0.78 & 0.64 & 0.25 & 0.233 \\
\hline budget year, i=1 & $\mathrm{CBO}$ & $1980-1998$ & -0.46 & 0.78 & 0.85 & 0.22 & 0.443 \\
\hline budget year, i=1 & FRB & $1980-1998$ & -0.58 & 0.79 & 0.83 & 0.22 & 0.417 \\
\hline$i=2$ & OMB & $1977-2003$ & -1.91 & 0.54 & 0.44 & 0.24 & 0.084 \\
\hline$i=2$ & OMB & 1978-2003 & -1.91 & 0.55 & 0.44 & 0.24 & 0.082 \\
\hline$i=2$ & CBO & 1978-2003 & -1.87 & 0.55 & 0.35 & 0.18 & 0.095 \\
\hline$i=3$ & OMB & $1978-2003$ & -2.59 & 0.53 & -0.02 & 0.30 & -0.041 \\
\hline$i=3$ & OMB & 1979-2003 & -2.59 & 0.55 & -0.02 & 0.31 & -0.043 \\
\hline$i=3$ & СВO & $1979-2003$ & -2.41 & 0.57 & 0.08 & 0.20 & -0.035 \\
\hline$i=4$ & OMB & 1979-2003 & -2.84 & 0.46 & -0.51 & 0.29 & 0.082 \\
\hline$i=4$ & OMB & $1980-2003$ & -2.89 & 0.47 & -0.51 & 0.29 & 0.082 \\
\hline$i=4$ & CBO & $1980-2003$ & -2.88 & 0.53 & -0.19 & 0.18 & 0.006 \\
\hline$i=5$ & OMB & $1980-2003$ & -2.75 & 0.39 & -0.80 & 0.24 & 0.312 \\
\hline$i=5$ & OMB & $1981-2003$ & -2.76 & 0.41 & -0.81 & 0.24 & 0.312 \\
\hline$i=5$ & $\mathrm{CBO}$ & $1981-2003$ & -3.01 & 0.48 & -0.34 & 0.14 & 0.174 \\
\hline
\end{tabular}




\begin{tabular}{|c|c|c|c|c|c|c|c|c|}
\hline & & Table IV & Test fo & ionalit & riance & & & \\
\hline forecaster & period & & & & izon & & & \\
\hline & & actual & $i=0$ & $i=1$ & $\mathrm{i}=2$ & $i=3$ & $i=4$ & $i=5$ \\
\hline OMB & $1980-98$ & 1.71 & 1.75 & 1.41 & 1.31 & 1.41 & 1.60 & $\overline{1.76}$ \\
\hline $\mathrm{CBO}^{*}$ & $1980-98$ & 1.71 & 1.62 & 1.39 & 1.68 & 2.24 & 2.87 & 3.56 \\
\hline FRB & $1980-98$ & 1.71 & 1.64 & 1.39 & & & & \\
\hline OMB & $1980-2003$ & 2.28 & 2.43 & 2.06 & 1.80 & 1.55 & 1.56 & 1.67 \\
\hline CBO* & $1980-2003$ & 2.28 & 2.40 & 2.31 & 2.35 & 2.37 & 2.70 & 3.20 \\
\hline OMB & $1950-2003$ & 1.88 & 1.98 & 1.77 & & & & \\
\hline
\end{tabular}

* $i=5$ range is only from 1981 onward 


\begin{tabular}{|c|c|c|c|c|c|c|c|}
\hline \multicolumn{8}{|c|}{ Table IV-4: Test for Rationality of Projections: } \\
\hline Forecast horizon & Forecaster & period & a & s.e. & $\mathrm{b}$ & s.e. & $\begin{array}{c}\text { Adjusted } \\
\text { R2 } \\
\end{array}$ \\
\hline \multicolumn{8}{|l|}{ Revenues } \\
\hline current year, $\mathrm{i}=0$ & OMB & $1980-2003$ & 2.21 & 2.00 & 0.88 & 0.11 & 0.74 \\
\hline budget year, i=1 & OMB & $1980-2003$ & 13.26 & 4.33 & 0.28 & 0.23 & 0.019 \\
\hline $\mathrm{i}=2$ & OMB & $1980-2003$ & 24.56 & 3.87 & -0.32 & 0.20 & 0.061 \\
\hline$i=3$ & OMB & $1980-2003$ & 28.72 & 3.05 & -0.54 & 0.16 & 0.309 \\
\hline$i=4$ & OMB & $1980-2003$ & 27.42 & 2.62 & -0.46 & 0.13 & 0.32 \\
\hline$i=5$ & OMB & $1980-2003$ & 24.56 & 2.27 & -0.31 & 0.12 & 0.215 \\
\hline \multicolumn{8}{|l|}{ Outlays } \\
\hline current year, $i=0$ & OMB & $1980-2003$ & 2.92 & 1.32 & 0.85 & 0.06 & 0.891 \\
\hline budget year, i=1 & OMB & $1980-2003$ & 3.77 & 2.58 & 0.83 & 0.12 & 0.657 \\
\hline$i=2$ & OMB & $1980-2003$ & 4.96 & 3.34 & 0.79 & 0.16 & 0.492 \\
\hline$i=3$ & OMB & $1980-2003$ & 10.92 & 3.74 & 0.50 & 0.19 & 0.217 \\
\hline$i=4$ & OMB & $1980-2003$ & 17.37 & 4.14 & 0.19 & 0.21 & -0.009 \\
\hline$i=5$ & OMB & $1980-2003$ & 21.55 & 4.12 & -0.02 & 0.21 & -0.045 \\
\hline \multicolumn{8}{|c|}{ errors as a percent of total receipts } \\
\hline Total receipts & $i=0$ & $i=1$ & $i=2$ & $\mathrm{i}=3$ & $\mathrm{i}=4$ & $\mathrm{i}=5$ & \\
\hline $1980-2003$ & 2.8 & 6.8 & 9.5 & 11.2 & 12.5 & 14.0 & \\
\hline $1987-2001$ & 3.1 & 5.0 & 6.9 & 8.1 & 8.6 & 9.1 & \\
\hline \multicolumn{8}{|l|}{ Individual income tax } \\
\hline 1980-2003 & 2.2 & 4.7 & 5.9 & 6.7 & 8.0 & 8.9 & \\
\hline $1987-2001$ & 2.3 & 3.9 & 5.3 & 6.2 & 6.4 & 6.5 & \\
\hline \multicolumn{8}{|l|}{ Corporate income tax } \\
\hline $1980-2003$ & 1.3 & 2.1 & 2.8 & 3.3 & 3.7 & 3.9 & \\
\hline $1987-2001$ & 1.3 & 1.5 & 2.0 & 2.5 & 2.5 & 2.6 & \\
\hline \multicolumn{8}{|l|}{ Social insurance } \\
\hline $1980-2003$ & 0.4 & 1.2 & 1.9 & 2.2 & 2.4 & 2.8 & \\
\hline $1987-2001$ & 0.3 & 1.0 & 1.6 & 2.0 & 2.4 & 2.7 & \\
\hline \multicolumn{8}{|l|}{ Other } \\
\hline 1980-2003 & 0.8 & 1.0 & 1.4 & 1.8 & 2.0 & 2.1 & \\
\hline $\begin{array}{l}1987-2001 \\
\text { error=(actual-forecast }\end{array}$ & tual & 0.5 & 0.7 & 1.0 & 1.5 & 1.5 & \\
\hline
\end{tabular}




\begin{tabular}{|c|c|c|c|c|c|c|c|}
\hline \multirow{2}{*}{\multicolumn{8}{|c|}{$\begin{array}{l}\text { Table IV-5: Test for Rationality of Projections } \\
\text { equation: } S(t)=a+b^{*} S F(t-i)+e\end{array}$}} \\
\hline & & & & & & & \\
\hline Forecast horizon & Forecaster & period & a & s.e. & $b$ & s.e. & $\begin{array}{l}\text { Adjusted } \\
\text { R2 }\end{array}$ \\
\hline current year, i=0 & OMB & $1980-1998$ & -0.12 & 0.41 & 0.88 & 0.10 & 0.801 \\
\hline current year, $\mathrm{i}=0$ & CBO & $1980-1998$ & 0.19 & 0.34 & 0.99 & 0.09 & 0.871 \\
\hline current year, $\mathrm{i}=0$ & FRB & 1980-1998 & 0.13 & 0.35 & 0.97 & 0.09 & 0.863 \\
\hline budget year, i=1 & OMB & 1980-1998 & -1.49 & 0.78 & 0.64 & 0.25 & 0.233 \\
\hline budget year, $\mathrm{i}=1$ & $\mathrm{CBO}$ & $1980-1998$ & -0.46 & 0.78 & 0.85 & 0.22 & 0.443 \\
\hline budget year, i=1 & FRB & $1980-1998$ & -0.58 & 0.79 & 0.83 & 0.22 & 0.417 \\
\hline \multicolumn{8}{|c|}{ Correlation of forecasts: 1980 to 1998} \\
\hline Current year & FRB & OMB & $\mathrm{CBO}$ & & & & \\
\hline FRB & 1.000 & 0.990 & 0.994 & & & & \\
\hline OMB & & 1.000 & 0.989 & & & & \\
\hline CBO & & & 1.000 & & & & \\
\hline Budget year & FRB & OMB & CBO & & & & \\
\hline FRB & 1.000 & 0.929 & 0.935 & & & & \\
\hline OMB & & 1.000 & 0.921 & & & & \\
\hline CBO & & & 1.000 & & & & \\
\hline \multicolumn{8}{|l|}{ RMSE of projections } \\
\hline & \multicolumn{2}{|c|}{$1980-1998$} & \multicolumn{2}{|c|}{$1980-2003$} & & & \\
\hline forecaster & $\mathrm{i}=0$ & $\mathrm{i}=1$ & $\mathrm{i}=0$ & $\mathrm{i}=1$ & & & \\
\hline FRB & 0.15 & 0.29 & n.a. & n.a. & & & \\
\hline OMB & 0.19 & 0.37 & 0.17 & 0.36 & & & \\
\hline CBO & 0.16 & 0.28 & 0.16 & 0.34 & & & \\
\hline \multicolumn{8}{|c|}{ Granger-Newbold test } \\
\hline & \multicolumn{2}{|c|}{$1980-1998$} & \multicolumn{2}{|c|}{$1980-2003$} & & & \\
\hline & $\mathrm{i}=0$ & $i=1$ & $\mathrm{i}=0$ & $i=1$ & & & \\
\hline OMB-СВО & 0.65 & 0.51 & 0.08 & 0.17 & & & \\
\hline OMB-FRB & 0.63 & 0.51 & n.a. & n.a. & & & \\
\hline FRB-CBO & 0.13 & 0.06 & n.a. & n.a. & & & \\
\hline \multicolumn{8}{|c|}{$\begin{array}{l}\text { Optimal weights } \\
\text { equation: } \mathrm{S}(\mathrm{t})=\mathrm{a}^{*} \mathrm{SF}(\mathrm{OMB}(\mathrm{t}-\mathrm{i}))+\mathrm{b}^{*} \mathrm{SF}(\mathrm{CBO}(\mathrm{t}-\mathrm{i}))+\mathrm{e}(\mathrm{t})\end{array}$} \\
\hline horizon & period & OMB & s.e. & CBO & s.e. & & \\
\hline current year & $1980-98$ & -0.95 & 0.49 & 1.93 & 0.50 & & \\
\hline current year & 1980-03 & 0.53 & 0.46 & 0.41 & 0.48 & & \\
\hline Budget year & $1980-98$ & -0.99 & 0.47 & 1.81 & 0.41 & & \\
\hline Budget year & 1980-03 & -0.30 & 0.66 & 1.18 & 0.57 & & \\
\hline
\end{tabular}

